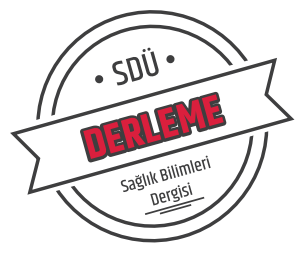

Sdü Sağlık Bilimleri Enstitüsü Dergisi / Cilt 9 Sayı 2 / 2018

\title{
Nöroinflamasyonun Epileptogenezdeki Rolü ve Antiepileptojenik Tedavide Nöroinflamasyona Yönelik Hedefler
}

\section{The Role of Neuroinflammation in Epileptogenesis and Antiepileptogenic Therapy Targets Directed to Neuroinflammation}

Erkan Aksöz ${ }^{1}$

${ }^{1}$ Süleyman Demirel Üniversitesi, Eczacılık Fakültesi, Farmakoloji Anabilim Dalı, Isparta, Türkiye.

\section{Özet}

Deneysel epilepsi modellerinde ve epilepsi hastalarında yapılan klinik çalışmalar sonucunda, nöroinflamasyonun epilepsi patofizyolojisinde etkin bir rolü olduğuna dair önemli kanıtlar elde edilmiştir. Özellikle, nöroinflamasyonla ilişkili yolaklar ve mediyatörlerin epileptogenez sürecindeki etkisi yoğun araştırma konusu olmuş, antiepileptojenik tedavilerin ve epileptojenik biyobelirteçlerin geliştirilebilmesi için bu süreçlerin aydınlatılması önem kazanmıştır. Bu çalışmalar sonucunda birçok patofizyolojik süreç incelenmiş ve antiepileptojenik tedavi hedefleri tanımlanmıştır. $\mathrm{Bu}$ derlemede epileptogenez sürecinde nöroinflamasyon ile ilişkili başlıca mekanizmalar ele alınmış, antiepileptojenik tedavi geliştirilmesi odaklı olarak potansiyel hedefler gözden geçirilmiştir.

Anahtar kelimeler: Nöroinflamasyon, Epileptogenez, Epilepsi, Antiepileptojenik, Sitokinler.

\begin{abstract}
Research in experimental epilepsy models and clinical investigations on epilepsy patients have provided important evidence that neuroinflammation has an effective role in epilepsy pathophysiology. Particularly, the effects of neuroinflammation-related pathways and mediators in the epileptogenesis process have been the subject of intensive research, and the elucidation of these processes has become important for the development of antiepileptogenic therapies and epileptogenic biomarkers. As a result of these studies, many pathophysiological processes have been determined and antiepileptogenic therapeutic targets have been defined. In this review, the main mechanisms involved in neuroinflammation in the epileptogenesis process are addressed and potential targets are reviewed focusing on developing antiepileptogenic therapy.
\end{abstract}

Keywords: Neuroinflammation, Epileptogenesis, Epilepsy, Antiepileptogenic, Cytokines.

\section{Giriş}

Nöroinflamasyon; mikroglia, astrositler ve kan beyin bariyerine katılan endotel hücrelerinin aktivasyonunu, plasma proteinlerinin ve immün sistem hücrelerinin beyin dokusuna infiltrasyonunu ve inflamasyon ilişkili mediatörlerin beyin dokusuyla etkileşimini içeren karmaşık bir olaydır (1). Birçok santral sinir sistemi hastalığında nöroinflamasyon bulguları saptanmaktadır ve epilepsi ile de nöroinflamasyon çoğu zaman birliktelik göstermektedir. Nöroinflamasyonun nöbet sıklığ1 ve şiddetini arttırdığına dair klinik ve deneysel araştırma ile çok sayıda kanıt elde edilmiştir (2). Şiddetli ve uzun süren nöroinflamasyonun eşlik ettiği otoimmun hastalıklarda ve ensefalit hastalarında da sı tekrarlayan nöbetler görülmekte ve antikonvülsan ilaçlara dirençli epilepsilerde de nöroinflamasyon bulgularına çoğunlukla rastlanmaktadır (3). $\mathrm{Bu}$ bulgular, nöroinflamasyonun epilepsi patogenezindeki önemini göstermiş ve antiepileptojenik tedavi geliştirmede bu mekanizmaların aydınlatılmasının önemini ortaya koymuştur.

\section{Epileptogenezde Patofizyoloji ve Araştırma Yöntemleri}

Epileptogenez, beyin dokusunda doğrudan veya dolaylı hasarların başlattığı patofizyolojik olaylar sonucunda, spontan nöbetler üretebilen beyin dokusunun gelişimini ve bu patolojik durumun ilerleme sürecini ifade eder $(4,5)$. Bu hasarlar doğuştan, genetik veya konjenital, olabilir veya kazanılmış hasarlar olabilir. Travma, infeksiyon, serebrovasküler olay veya febril konvulsiyonlar epileptogenez sürecini başlatabilir (6).

Epileptogenez sürecinin başlamasından hastalığın yerleşmesine kadar olan bir latent dönem vardır. Ancak bu latent dönem hasarın başlangıcından klinik olarak nöbetlerin ortaya çıkmasına kadar olan dönemi ifade etmektedir. Esas olarak epileptogenezin sürekli bir patofizyolojik olay olduğu ve nöbetlerin ortaya çıkmasından sonra da ilerleyici olduğu düşünülmektedir (7-9). Klinik çalışmalarda da Temporal Lob Epilepsisi (TLE)'nin ilerleyici olduğuna dair kanıtlar elde edilmiştir (8).
DOI: $10.22312 /$ sdusbed. 421087

Müracaat tarihi: 04.05 .2018

Kabul tarihi: 10.05 .2018
Yazışma Adresi / Corresponding: Erkan Aksöz,
Sağllk Mahallesi A. Adnan Saygun 2 Cad No: 5506100 Sihhıye/Çankaya, Ankara, Türkiye.
Tel: +90 3125655451
E-mail: erkanaksoz@yahoo.com 
Epileptogenezin araştırılmasına yönelik çok sayıda deneysel hayvan modeli geliștirilmiştir (9). Așağıda belirtilen araştırmalarda genellikle kainat veya pilokarpin enjeksiyonu ile oluşturulan SE (Status epilepticus) sonrası başlatılan epileptogenez modelleri kullanılmıştır. Elektriksel ve kimyasal kindling modelleri de epileptogenezin araştırılmasında kullanılan önemli modellerdir ve insanda TLE'de saptanan patolojik değișimlerle büyük oranda benzerlik göstermektedir. Travmatik beyin hasarının modellenmesinde sıvı-perküsyon hasarı yöntemi ve kontrollü kortikal darbe yöntemi genellikle kullanılan yöntemlerdir (9, 10).

İnsanda epileptogenez sürecinin çalışılması çeşitli zorluklar içermekle birlikte başlangıç hasarı öncesi ve sonrasında epilepsi gelişiminin geriye ve ileriye dönük istatistiksel analizleri, cerrahi tedavi sonrası elde edilen numunelerin patolojik ve moleküler incelemeleri, hastalardaki EEG ölçümleri ve görüntüleme yöntemleri ile elde edilen veriler önemli bilgiler sağlamıştır $(9,10)$.

İlaca dirençli epilepsilerin büyük bir kısmını oluşturan TLE'de, epileptogenez sürecinde nöronal ve glia hücrelerinin organizasyonunda önemli değişimler meydana gelmektedir. En çok incelenen bölgelerden biri olan hipokampusta, yosunsu lif filizlenmesi, hipokampal skleroz ve nöronal hücre kaybı görülmekte, nöral ağlarda kısa ve uzun dönemli sinaptik plastisite değişimleri oluşmaktadır (8).

\section{Antiepileptojenik Tedavi Geliştirilmesinin Önemi}

Antiepileptojenik tedavi, ILAE (International League Against Epilepsy) tarafından ayrıntılı olarak tanımlanmış ve güncellenmiştir. Buna göre antiepileptojenik tedavi, epileptogenez sürecini başlatan olay sonrasında epilepsi gelişiminin engellenmesi ve eğer nöbetler başladıysa hastalığın ilerlemesini durdurmayı ve hatta geri döndürmeyi amaçlamaktadır. Ayrıca anksiyete, depresyon, somatomotor bozukluklarve bilişsel fonksiyonlarda gerileme gibi epilepsiye bağlı komorbiditelerin de iyileştirilmesini hedeflemektedir. Epilepside hastalığı modifiye edici tedaviler, tanım olarak nöbetler başladıktan sonraki antiepileptojenik tedaviyi içermektedir. Sadece nöbetleri engelleyen ve nöbet şiddeti, sıklığına ve hastalığın ilerleyişine etki etmeyen tedaviler antiepileptojenik tedavi olarak değerlendirilmemektedir (8).

Mevcut epilepsi tedavileri büyük oranda nöbet kontrolüne yöneliktir ve hastalığı modifiye edici etkileri yetersizdir. Antiepileptojenik tedavi geliştirilmesi ile, başlangıç hasarına neden olay sonrası epilepsi gelişmesinin engellenebileceği, hastalığın mortalite ve morbiditesinin azaltılacağı ve mevcut ilaçlara dirençli epilepsilerin kontrol altına alınabilmesinin sağlanabileceği düşünülmektedir (7).

\section{Epileptogenezde Nöroinflamasyonun Rolü}

Beyin dokusunda hasara yol açan herhangi bir olay beyinde inflamasyon sürecini başlatabilir. Hatta santral sinir sistemi dışında başlayan sistemik inflamasyonlar da, mikroglia, astrositler ve kan beyin bariyerinde bulunan endotel hücreleri ile, inflamatuvar mediyatörler aracılığıyla etkileşim halinde olduğundan, kan beyin bariyerinin bozulmasına ve nöroinflamasyonun başlamasına neden olabilmektedir. $\mathrm{Bu}$ nedenle, kan beyin bariyeri, santral sinir sistemini, beyin dışında meydana gelen inflamasyondan tamamen izole edememektedir $(1,2)$.

Travmatik beyin hasarı, infeksiyon, serebrovasküler olay, otoimmün ve paraneoplastik hastalıklarda oluşan antikorlar ve bazı genetik hastalıklar nöroinflamasyonu başlatan hasarı oluşturabilen etmenlerdir (3). Epileptik nöbetler sırasında oluşan yoğun nöronal aktivitenin de nöroinflamasyonu başlatabileceğine dair çok sayıda kanıt elde edilmiştir. Absans epilepsi nöbetlerinde oluşan yoğun talamokortikal aktivitenin de nöroinflamasyona yol açabildiği bildirilmiştir (11). Uzun süreli epileptik nöbetlerin beyinde akut immün ve inflamatuvar yanıt oluşumunu başlattığı ve tekrarlayan nöbetlerin kronik inflamasyona neden olduğu hayvan modellerinde ve insanda yapılan çalışmalarda gösterilmiştir (1).

Nöroinflamasyonun oluşumunu tetikleyen "başlangıç hasarı", nitelik ve şiddetine bağlı olarak, mikroglia ve astrositlerin uyarılmasına, inflamatuvar mediyatörlerin ve sitokinlerin salınmasına neden olmaktadır. Bu hasar sonrası nöronlar da sürece dahil olmakta ve tehlike sinyali denilen moleküllerin hücre dışına çıkışı gerçekleşmektedir. Bu olaylar sonucu ortaya çıkan mediyatörler astrosit ve endotel hücrelerini etkileyerek kan beyin bariyerinin (KBB) geçirgenliğinin artmasına ve albuminin serebrosinal sıvıya geçmesine neden olmaktadır. Albumin ise proinflamatuvar bir sinyal oluşturarak nöroinflamasyon ilişkili diğer yolaklarda aktivasyona neden olmaktadır (1, 12). Nöroinflamasyon sirasında aktive olan başlıca yolaklar, epileptogenez ile ilişkisi ve potansiyel tedavi hedefleri aşağıda gözden geçirilmiştir.

\section{Epileptogenezde Nöroinflamasyonla İlişkili Yolaklar ve Potansiyel Tedavi Hedefleri}

\section{COX-2 ve Prostaglandinler}

Siklooksijenaz enzimlerinin indüklenebilir formu olan COX-2'nin insanda ve deney hayvanlarında nöbet sonrasında indüklendiği gösterilmiştir. COX-2'nin nöronal ekspresyonundaki artış, farelerde deneysel olarak kainat ile oluşturulan nöbetlerde ve nöbete bağlı mortalitede artışa neden olmuştur. COX-2 geni silinmiş farelerde nöbet eşiği artmış ve nöbetlerin şiddeti azalmıştır. Bu bulgular COX2 indüksiyonunun epileptogenezde rolü olabileceğini düşündürmüştür. COX-2 inhibitörleri ile yapılan çalışmalarda, nöbet sonrasında bu ajanların uygulanmasının nöronal koruyucu etki gösterdiği saptanmıştır ancak selektif COX2 inhibitörlerinin birçoğunda antiepileptojenik etki elde edilememiştir. Kardiyovasküler yan etkileri nedeniyle bu ilaçların antiepileptojenik amaçla ancak kısa süreli ve düşük dozda kullanımının mümkün olabileceği belirtilmiştir (1).

Tüm prostaglandin türlerinin sentezini inhibe eden COX2 inhibitörleri yerine daha spesifik etki elde edilebilecek prostaglandin reseptörleri üzerine çalışmalar yapılmıştır. $\mathrm{PGE}_{2}$ 'nin nöroinflamasyonda EP1 ve EP2 reseptörleri aracılığıyla önemli rol oynadığ1, EP1 antagonisti SC51089'un ve EP2 antagonisti TG4-155'in nöroinflamasyonu azaltıc1 ve nöroprotektif etkileri olduğu saptanmıştır. $\mathrm{PGE}_{2}$ 'nin proinflamatuvar yöndeki etkilerine zit olarak, 
$\mathrm{PGD}_{2}$ ve $\mathrm{PGF}_{2} \alpha$ ise kainat injeksiyonu sonrası farelerde nöbet sıklığını ve şiddetini ve mortaliteyi azaltıcı etki göstermiştir. Prostaglandin reseptörleri potansiyel hedef olarak görülmekle birlikte daha çok veriye ve bu reseptörlere etki eden yeni moleküllerin geliştirilmesine ihtiyaç vardır (1).

\section{Monoaçil Gliserol Lipaz (MAGL) Yolağı}

Sitozolik fosfolipaz A2 geni silinmiş farelerde beyindeki araşidonik asit düzeylerinin değişmediğinin gözlenmesiyle, beyinde araşidonik asit oluşumunda başka bir yolağın olabileceği düşünülmüş ve 2-araşidonil gliserolün hidrolizini sağlayan MAGL enziminin bu oluşumdan sorumlu olduğu bulunmuştur. Bu enzimin nöroinflamasyona yönelik tedavide bir hedef olabileceği belirtilmiştir (13). Bu hedefe yönelik bir araştırmada, potent ve selektif MAGL inhibitörü uygulanması ile benzodiazepine dirençli status epileptikus modelinde nöbetin şiddeti ve süresinin azaldığ gösterilmiş ve bu etkinin ketojenik diyet alan farelerde daha güçlü olduğu saptanmıştır (14). MAGL enziminin JZL184 ile selektif olarak inhibe edilmesiyle farelerde kindling oluşumunun geciktirildiğini gösteren bir çalışmada da bu enzimin, antiepileptojenik tedavi yaklaşımında umut verici bir hedef olabileceği belirtilmiştir (15).

\section{Oksidatif Stres}

Reaktif oksijen türlerinin (ROT) oluşumu ve detoksifikasyonundaki dengesizlikten kaynaklanan oksidatif stres, beyinde inflamasyon, yaşlanma ve dejenerasyonda önemli rol oynamaktadır. Aktive NOX (NADPH Oksidaz) enzimleri ROT oluşumunda ana etkendirler ve beyinde özellikle NOX2; Parkinson, Alzheimer, amyotrofik lateral skleroz ve epilepsi hastalıklarının patofizyolojisinde önemlidir (1). Farede kainat ve pilokarpin ile oluşturulan SE modellerinde ROT üretiminin arttığ1, NOX2 enziminin indüklendiği ve mikroglia uyarımının gerçekleştiği saptanmış ve bu etkilerin NOX2 inhibitörü aposinin ile baskılandığ gösterilmiştir $(16,17)$. Aposininin Rho-Kinaz inhibisyonu ve belirgin ROT süpürücü etkisinden dolayı daha spesifik NOX2 inhibitörleri geliştirilme aşamasındadır ve antiepileptojenik etkilerinin araştırılması gerekmektedir (1).

\section{Sitokinler ve İlişkili Yolaklar}

Sağlıklı beyinde düşük düzeylerde bulunan IL-1 $\beta$, IL-6 ve $\mathrm{TNF} \alpha$ gibi proinflamatuvar sitokinler, akut beyin hasarı ve nöbetler sonrasında hızlı bir artış göstermektedir (18). Bu sitokinlerle ilişkili yolakların epileptogenezde etkisi olup olmadığı hayvan modellerinde incelenmiştir.

\section{IL-1 $\beta$ yolağı ve TLR (Toll-like reseptörler)}

Beyinde inflamasyonu başlatan olaylar (travma, enfeksiyon, serebrovaskuler olay, nöbetler vs.) mikroglia ve astrositlerde IL-1 $\beta$ sentezlenmesine neden olur. IL-1 $\beta$, kaspaz1/ Interlökin dönüştürücü enzim (İDE) ile pro- formundan aktif formuna dönüştürülmektedir. IL-1 $\beta$ etkilerini IL-

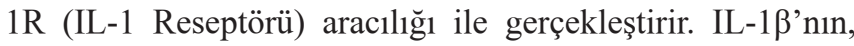
astrositlerden glutamat gerialımını inhibe ederek ve NMDA Reseptör aktivitesini artırarak nöronal eksitabilitede artışa neden olduğu saptanmıştır. Bu bulgu, IL-1R antagonisti IL1RA'nın intrahipokampal enjeksiyonu sonrası, farelerde kainat ve bikukullin ile oluşturulan nöbetleri engellediğinin gösterilmesiyle de desteklenmiştir (1, 19). Diğer bir çalışmada IL-1RA'nın status epilepticus sonrası kan beyin bariyerindeki bozulmayı engellediği saptanmış (20) ayrıca lipopolisakkarid (LPS) ile indüklenen nöroinflamasyonu baskıladığı gözlenmiştir (21).

IL-1R ve TLR yüksek oranda yapısal benzerlik gösteren reseptörlerdir. TLR4, LPS algılayıcısı olarak görev yapmaktadır ve endojen olarak HMGB1 (High Mobility Group Box1) proteini ile uyarılmaktadır. HMGB1, beyin dokusunda hasar durumunda mikroglia ve astrositler tarafından salınmakta ve tehlike sinyali olarak görev yapmaktadır. Ayrıca Kaspaz-1'in aktivasyonu da HMGB1 salınmasında artışa neden olmaktadır (14). Kaspaz-1'in VX765 ile inhibisyonunun astrositlerden HMGB1 salınmasını engelleyerek epileptogenezi baskıladığı bildirilmiştir (22). VX-765' in sistemik uygulaması ile fare modellerinde akut nöbetlerin ve ilaca dirençli kronik nöbetlerin baskılandığ 1 saptanmıştır (23). Deneysel modellerde, epileptogenez sürecinde IL-1 $\beta$ ve HMGB1 yolaklarının birlikte aktivasyonunun gerçekleştiği ve bu yolakların her ikisinin inhibisyonunun antiepileptojenik etki ortaya çıkardığ 1 belirlenmiştir (14).

Yakın zamanda yapılan iki çalışmada, farelerde akut ve kronik epilepsi modellerinde, anti-HMGB1 monoklonal antikoru (mAb) uygulamasının, kan beyin bariyerindeki bozulmayı önlediği ve epileptogenez sürecini uzattığg bildirilmiştir (24, 25).

\section{TNFo}

Epileptik nöbetlerin deneysel modellerde TNF $\alpha$ düzeylerinde artışa neden olduğu bilinmektedir ve nöbet oluşturulan hayvanlara, deneysel modellerde TNF $\alpha$ uygulamasının nöbet sıklığ 1 ve şiddetini arttırdığı saptanmıştır(18). Bununla birlikte, TNF $\alpha$ 'nın TNFR1 reseptörü aracılığıyla prokonvülsan etki ve TNFR2 reseptörü aracılığıyla antikonvülsan etki gösterdiği bulunmuştur $(26,27)$. Bu reseptörlerin uzun dönemli sinaptik değişimlere neden olarak epileptogenezde rolü olabileceği belirtilmiştir (28).

\section{IL6}

IL6 artışı epilepsi hastalarında ve deneysel epilepsi modellerinde siklıkla gözlenmektedir. IL6 reseptör aracılı etkilerle NFאB uyarımı gerçekleşmekte ve COX2 indüklenerek prokonvulsan etkili PGE2 artışı meydana gelmektedir. IL6'nın prokonvulsan etkisi sıçan ve fare epilepsi modellerinde gösterilmiştir. IL6 reseptörleri antiepileptojenik tedavide bir hedef olarak görünmekle birlikte henüz bu hedefe yönelik ajanlar geliştirilme aşamasındadır (1).

\section{TGF $\beta / A L K 5$ yolağı}

Kan beyin bariyerinin bozulmasina neden olan olaylar veya intra serebroventriküler albumin injeksiyonu, astrositlerde TGFß/ALK5 yolağının aktive olmasına, bunun sonucunda da eksitasyon yönünde sinaptogenez oluşmasına yol açmaktadır. $\mathrm{Bu}$ sürecin spontan nöbetlerin oluşumuna kadar giden bir epileptogenez sürecine katkıda bulunduğuna dair kanıtlar elde edilmiştir (1). Albumin ile oluşturulan sinaptogenez ve 
nöbetlerin, spesifik bir TGFß/ALK5 yolağı inhibitörü olan SJN2511 tarafından önlendiği (29), Anjiotensin II reseptör antagonisti losartan ile de bu yolağın baskılandığı ve spontan nöbet oluşumunun engellendiği bildirilmiştir (30).

\section{mTOR (mammalian Target of Rapamycin) yolağı}

mTOR yolağı hücre büyümesi, farklılaşması, çoğalması ve metabolizması üzerinde önemli rol oynamaktadır. Bu yolağın aktivasyonu, ribozomal S6 kinaz ve 4E-bağlayıc1protein1 (4EBP1) gibi translasyonu düzenleyen proteinlerin fosforilasyonuna neden olur (31). TSC1, TSC2 ve PTEN gibi tumor baskılayıcı genlerin mutasyonu ile birliktelik gösteren epilepsi sendromlarında (tuberoskleroz, Cowden hastalığı vs.) mTOR yolağında hiperaktivasyon saptanmıştır $(32,33)$. SE ile oluşturulan epilepsi modellerinde rapamisin ile mTOR yolağının inhibe edilmesinin nöbet sıklığını, nöronal hücre kaybını, yosunsu lif filizlenmesini ve KBB bozulmasını azalttığ1 bildirilmiştir. Bununla birlikte bu etkilerin rapamisinin 6 hafta sürekli kullanımında ortaya çıktığı, bu etkilerin antiepileptojenik etki yanında kısmen semptomatik nöbet baskılayıcı etkiden kaynaklanabileceği de belirtilmiştir (14).

mTOR yolağının immunoproteazom oluşumu ile de ilişkili olduğuna dair kanıtlar elde edilmiştir. SE ile oluşturulan epileptogenez modelinde immünoproteazom ekspresyonunun arttığ1 gösterilmiş (34), bu bulguyu teyit eden diğer bir çalışmada da epileptogenez sırasında artan immunoproteazom ekspresyonunun rapamisin uygulaması ile baskılandığı bildirilmiştir (35). Rapamisinin mTOR yolağı haricinde etkilerinin de olması ve yan etkileri nedeniyle mTOR yolağının antiepileptojenik etkilerinin araştırilmasına daha spesifik ajanlarla devam edilmesi gerekliliği belirlenmiştir $(14,33)$.

\section{MikroRNA'lar}

Hücrede birçok fizyolojik olayda düzenleyici rol oynayan mikroRNA (miRNA)'lar 21-23 oligonükleotidten oluşan moleküllerdir. $\mathrm{Bu}$ düzenleyici fonksiyonları nedeniyle birçok hastalığın tedavisi için yeni bir terapötik hedef olarak görülmektedirler. Nöroinflamasyonla ilişkili olarak proinflamatuvar (miR-155, miR-27b, miR-326) antiinflamatuvar (miR-124, miR-146a, miR-21, miR-223) ve karışık etkili (let-7 ailesi) miRNA'lar belirlenmiştir (36). Bir çalışmada, fare TLE modelinde miR-146a benzeri (mimic) kullanılarak IL1/TLR4 sinyal yolağının inhibe edilmesi ile, nöbet sıklığının önemli ölçüde azaldığı saptanmıştır (37). Fare modellerinde miR-128 ekspresyonunun bloke edilmesi ölümcül epilepsi ile sonuçlanmış, artırılması ise kainik asit ile uyarılan nöbetlerde azalma ve nöroprotektif etki göstermiştir (38). miR-134'ü sessizleştiren miR antagomiri ile de kainik asit ile oluşturulan SE sonrasında kronik spontan nöbetlerde azalma görülmesi antiepileptojenik etkiyi düşündürmüştür (39). Epileptogenez ile ilişkili birçok proteinin ekspresyonunun düzenlenmesinde rolü olan miRNA'lar antiepileptojenik tedavide önemli bir hedef olarak görülmektedir (40).

\section{Kemokin İlişkili Yolaklar}

Kemokinler, kemotaktik özelliğe sahip sitokinlerdir. İnflamasyon durumunda kemokinler, beyinde endotel adezyon moleküllerinin artmasını sağlayarak lökositlerin kan beyin bariyerini geçmesine ve kemotaktik etki ile bu hücrelerin nöroinflamasyon bölgelerine göçmesine neden olur. Mikroglia ve astrositlerden salgılanan kemokinler de nöroinflamasyonda rol oynar. Farelerde LPS ile deneysel olarak oluşturulan sistemik inflamasyonun spontan nöbet geçiren farelerde nöbet şiddeti ve sıklığını artırdığ1 saptanmış, nöroinflamasyonda önemli rol oynadığ 1 bildirilen bir kemokin olan CCL2'nin bu farelerin beyninde arttığ1 saptanmıştır. CCL2 yolağının, bu kemokinin reseptörü olan CCR2'nin antagonisti RS102895 veya CCL2 transkripsiyon inhibitörü bindarit ile inhibe edilmesi ile LPS nin nöbetleri artırıcı etkileri baskılanabilmiştir (14).

\section{Sonuç}

Nöroinflamasyonla ilişkili yolakların epileptogenez sürecine etkisinin incelenmesi çok sayıda potansiyel tedavi hedefi ortaya çıkarmıştır. Epilepsi türüne ve hastaya bağlı olarak nöroinflamasyon farklı yolakların eşzamanlı veya zincirleme aktivasyonu ile gerçekleşebilmekte, bu nedenle birçok yolağ1 hedef alan kombine immun-modüle edici ve antiinflamatuvar tedavilerin kullanımı ile antiepileptojenik etkinin elde edilmesinin mümkün olabileceği düşünülmektedir (14). Deneysel modellerde antiepileptojenik etki gösterdiği saptanan ajanların farmakodinamik ve farmakokinetik özelliklerinin geliştirilmesiyle kliniğe uyarlanabilmesi mümkün olabilecektir (1). Epileptogenezde nöroinflamasyon ilişkili süreçlerin daha iyi anlaşılması epileptojenik biyobelirteçlerin geliştirilmesine de katkıda bulunacaktır (6).

\section{Kaynaklar}

1. Dey A, Kang X, Qiu JG, Du YF, Jiang JX. AntiInflammatory small molecules to treat seizures and epilepsy: From bench to bedside. Trends Pharmacol Sci. 2016; 37(6): 463-84.

2. Vezzani A, Aronica E, Mazarati A, Pittman QJ. Epilepsy and brain inflammation. Exp Neurol. 2013; 244: 11-21.

3. Vezzani A. Epilepsy and inflammation in the brain: Overview and pathophysiology. Epilepsy Curr. 2014; 14: 3-7.

4. Vezzani A, Ruegg S. Introduction to the 2nd Meeting on Immunity and Inflammation in Epilepsy (IIE2016). Epilepsia. 2017; 58: 7-10.

5. Pitkanen A, Engel J. Past and present definitions of epileptogenesis and its biomarkers. Neurotherapeutics. 2014; 11(2): 231-41.

6. Terrone G, Pauletti A, Pascente R, Vezzani A. Preventing epileptogenesis: A realistic goal? Pharmacol Res. 2016; 110: 96-100.

7. Schmidt D, Sillanpaa M. Evidence-based review on the natural history of the epilepsies. Current Opinion in Neurology. 2012; 25(2): 159-63.

8. Pitkanen A, Lukasiuk K, Dudek FE, Staley KJ. 
Epileptogenesis. Csh Perspect Med. 2015; 5(10): a022822-a022838.

9. Becker AJ. Review: Animal models of acquired epilepsy: insights into mechanisms of human epileptogenesis. Neuropathol Appl Neurobiol. 2018; 44(1): 112-29.

10. D’Ambrosio R, Eastman CL, Fattore C, Perucca E. Novel frontiers in epilepsy treatments: preventing epileptogenesis by targeting inflammation. Expert Rev Neurother. 2013; 13(6): 615-25.

11. Akin D, Ravizza T, Maroso M, Carcak N, Eryigit T, Vanzulli I, et al. IL-1 beta is induced in reactive astrocytes in the somatosensory cortex of rats with genetic absence epilepsy at the onset of spike-and-wave discharges, and contributes to their occurrence. Neurobiol Dis. 2011; 44(3): 259-69.

12. Ravizza T, Gagliardi B, Noe F, Boer K, Aronica E, Vezzani A. Innate and adaptive immunity during epileptogenesis and spontaneous seizures: Evidence from experimental models and human temporal lobe epilepsy. Neurobiol Dis. 2008; 29(1): 142-60.

13. Nomura DK, Lombardi DP, Chang JW, Niessen S, Ward AM, Long JZ, et al. Monoacylglycerol lipase exerts dual control over endocannabinoid and fatty acid pathways to support prostate cancer. Chem Biol. 2011; 18(7): 846-56.

14. Aronica E, Bauer S, Bozzi Y, Caleo M, Dingledine R, Gorter JA, et al. Neuroinflammatory targets and treatments for epilepsy validated in experimental models. Epilepsia. 2017; 58: 27-38.

15. von Ruden EL, Bogdanovic RM, Wotjak CT, Potschka H. Inhibition of monoacylglycerol lipase mediates a cannabinoid 1-receptor dependent delay of kindling progression in mice. Neurobiol Dis. 2015; 77: 238-45.

16. Patel M, Li QY, Chang LY, Crapo J, Liang LP. Activation of NADPH oxidase and extracellular superoxide production in seizure-induced hippocampal damage. J Neurochem. 2005; 92(1): 123-31.

17. Kim JH, Jang BG, Choi BY, Kim HS, Sohn M, Chung TN, et al. Post-treatment of an NADPH oxidase inhibitor prevents seizure-induced neuronal death. Brain Res. 2013; 1499: 16372 .

18. Vezzani A, French J, Bartfai T, Baram TZ. The role of inflammation in epilepsy. Nat Rev Neurol. 2011; 7(1): 31-40.

19. Vezzani A, Moneta D, Conti M, Richichi C, Ravizza T, De Luigi A, et al. Powerful anticonvulsant action of IL-1 receptor antagonist on intracerebral injection and astrocytic overexpression in mice. Proc Natl Acad Sci U S A. 2000; 97(21): 11534-9.

20. Marchi N, Fan Q, Ghosh C, Fazio V, Bertolini F, Betto $\mathrm{G}$, et al. Antagonism of peripheral inflammation reduces the severity of status epilepticus. Neurobiol Dis. 2009; 33(2): 171-81.

21. Auvin S, Shin D, Mazarati A, Sankar R. Inflammation induced by LPS enhances epileptogenesis in immature rat and may be partially reversed by IL1RA. Epilepsia. 2010; 51 (3): 34-8.
22. Ravizza T, Noe F, Zardoni D, Vaghi V, Sifringer M, Vezzani A. Interleukin Converting Enzyme inhibition impairs kindling epileptogenesis in rats by blocking astrocytic IL1beta production. Neurobiol Dis. 2008; 31(3): 327-33.

23. Maroso M, Balosso S, Ravizza T, Iori V, Wright CI, French $\mathrm{J}$, et al. Interleukin-1 beta biosynthesis inhibition reduces acute seizures and drug resistant chronic epileptic activity in mice. Neurotherapeutics. 2011; 8(2): 304-15.

24. Fu L, Liu KY, Wake H, Teshigawara K, Yoshino T, Takahashi $\mathrm{H}$, et al. Therapeutic effects of anti-HMGB1 monoclonal antibody on pilocarpine-induced status epilepticus in mice. Sci Rep. 2017; 7(1): 1179-1191.

25. Zhao JL, Wang Y, Xu CL, Liu KY, Wang Y, Chen LY, et al. Therapeutic potential of an anti-high mobility group box-1 monoclonal antibody in epilepsy. Brain Behavior and Immunity. 2017; 64: 308-19.

26. Balosso S, Ravizza T, Perego C, Peschon J, Campbell IL, De Simoni $\mathrm{MG}$, et al. Tumor necrosis factor-alpha inhibits seizures in mice via p75 receptors. Ann Neurol. 2005; 57(6): 804-12.

27. Weinberg MS, Blake BL, McCown TJ. Opposing actions of hippocampus TNFalpha receptors on limbic seizure susceptibility. Exp Neurol. 2013; 247: 429-37.

28. Iori V, Frigerio F, Vezzani A. Modulation of neuronal excitability by immune mediators in epilepsy. Curr Opin Pharmacol. 2016; 26: 118-23.

29. Weissberg I, Wood L, Kamintsky L, Vazquez O, Milikovsky DZ, Alexander A, et al. Albumin induces excitatory synaptogenesis through astrocytic TGF-beta/ALK5 signaling in a model of acquired epilepsy following bloodbrain barrier dysfunction. Neurobiol Dis. 2015; 78: 115-25.

30. Bar-Klein G, Cacheaux LP, Kamintsky L, Prager O, Weissberg I, Schoknecht K, et al. Losartan prevents acquired epilepsy via TGF-beta signaling suppression. Ann Neurol. 2014; 75(6): 864-75.

31. Inoki K, Corradetti MN, Guan KL. Dysregulation of the TSC-mTOR pathway in human disease. Nat Genet. 2005; 37(1): 19-24.

32. Crino PB. mTOR: A pathogenic signaling pathway in developmental brain malformations. Trends Mol Med. 2011; 17(12): 734-42.

33. Galanopoulou AS, Gorter JA, Cepeda C. Finding a better drug for epilepsy: The mTOR pathway as an antiepileptogenic target. Epilepsia. 2012; 53(7): 1119-30.

34. Mishto M, Ligorio C, Bellavista E, Martucci M, Santoro $\mathrm{A}$, Giulioni $\mathrm{M}$, et al. Immunoproteasome expression is induced in mesial temporal lobe epilepsy. Biochem Bioph Res Co. 2011; 408(1): 65-70.

35. Broekaart DWM, van Scheppingen J, Geijtenbeek $\mathrm{KW}$, Zuidberg MRJ, Anink JJ, Baayen JC, et al. Increased expression of (immuno)proteasome subunits during epileptogenesis is attenuated by inhibition of the mammalian target of rapamycin pathway. Epilepsia. 2017; 58(8): 146272 . 
36. Gaudet AD, Fonken LK, Watkins LR, Nelson RJ, Popovich PG. MicroRNAs: Roles in Regulating Neuroinflammation. Neuroscientist. 2017:1073858417721150.

37. Iori V, Iyer AM, Ravizza T, Beltrame L, Paracchini L, Marchini S, et al. Blockade of the IL-1R1/TLR4 pathway mediates disease-modification therapeutic effects in a model of acquired epilepsy. Neurobiol Dis. 2017; 99: 12-23.

38. Tan CL, Plotkin JL, Veno MT, von Schimmelmann M, Feinberg P, Mann S, et al. MicroRNA-128 governs neuronal excitability and motor behavior in mice. Science. 2013; 342(6163): 1254-58.

39. Jimenez-Mateos EM, Engel T, Merino-Serrais $P$, McKiernan RC, Tanaka K, Mouri G, et al. Silencing microRNA-134 produces neuroprotective and prolonged seizure-suppressive effects. Nat Med. 2012; 18(7): 1087-94.

40. Patel DC, Wilcox KS, Metcalf CS. Novel targets for developing antiseizure and, potentially, antiepileptogenic drugs. Epilepsy Curr. 2017; 17(5): 293-8. 